\title{
Ethnic or Religious Identities?: Multicultural Analysis in Australia from Socio-Demographic Perspective
}

\author{
Yaghoob Foroutan 1 \\ Department of Social Sciences, University of Mazandaran, Iran
}

\begin{abstract}
Focusing on the data of ethnic and religious identities in a multiethnic and multicultural context, this paper provides research-based evidence to explain whether and how significantly such data could be reliable from a social and demographic perspective. The explanation is based on population census that also provides unique nation-wide data sources on 'religious affiliation'. The field of this study is the multiethnic and multicultural context of Australia that holds a large variety of ethnic, religious and cultural groups from throughout the world. According to the findings of the present analysis, this paper argues that if ethnic migrants belonging to the same category of religious affiliation are considered as a single group without taking their ethnic origins into account, this will lead to insufficient, incomplete, and misleading knowledge.

Keywords: ethnic and religious identities, multicultural Australia, social and demographic characteristics.
\end{abstract}

\section{Introduction}

Dealing with data on ethnic and religious identities in a multiethnic and multicultural context, this paper provides research-based evidence to explain whether and how significantly such data could be reliable from a social and demographic perspective. It presents researchbased evidence to examine this key research question: 'how reliable would our analysis on ethnic migrants' religion be if we used official data sources?'. In particular, this paper provides empirical evidence to explore the existence and the extent of the reliability of studies on immigrants' religion based on official data. Population censuses are the most commonlyused and the most representative sources of data, which also applies to migration studies. The official statistics through population censuses identify 'religious affiliation', which also provide a unique data source in nation-wide to compare demographic characteristics of natives and migrants. However, this paper argues that the term 'religious affiliation' needs to be considered carefully as it may provide incomplete and misleading knowledge on the religious identity of immigrants. This particularly applies both to multicultural contexts (as destinations of migration) and to the immigrants who experience greater 'cultural distance' (e.g., AddaiMununkum, 2019; Berry, 1992; Chiswick et al. 2003; Bevelander, 2005; Foroutan, 2009a, 2017; Krynski, 2019; Wilder, et al, 2017). This particular application lies in the fact that not only such multicultural destinations of migration lead to a substantially wide range of ethnic diversity of migrants who share the same religious affiliation but also the degree of the religious affiliation of migrants experiencing greater cultural distance between origin and destination societies remains as a crucial issue upon migration. Further, it tends to be a more crucial issue when we

${ }_{1}$ Correspondence: Associate Professor of Demography at the Department of Social Sciences, University of Mazandaran, Babolsar, Iran. Research Associate, The University of Waikato Islamic Studies Group, Hamilton, New Zealand.

Adjunct Fellow, School of Social Sciences and Psychology,Western Sydney University, Sydney, Australia.

E-mail: y_foroutan@yahoo.com 
deal with people migrating from the East to the West. This is mainly a consequence of religious socialization process in different placesbefore migration on one hand, and being in the exposure of secularization experience after migration on the other hand: while they are largely socialized in places where religion traditionally plays a fundamental role in individual and societal life, their current residing society is a Western-oriented place where such phenomenon as 'fuzzy fidelity' (Voas, 2009), 'no religion' and secularization (Kaufman et al. 2012) are becoming increasingly more predominant. In the next sections, this paper presents information about contemporary literature, the field of this study, data and methodology. Then, it provides a brief settlement history and the main socio-demographic characteristics of the focus group of this study. Finally, the paper presents and explains the key major patterns observed in the present study.

\section{Background: Muslim Migrants in the West}

This section reviews briefly the literature focusing on the status of Muslim migrants in the western context. The review focuses particularly on Muslim migrants in European countries. The discussion on the settlement and demographics of Muslim migrants of this study will be presented in the next section. Generally speaking, the population of Muslim migrants in Europe, as in other western settings, has received increasingly significant attention in contemporary literature. This mainly liesin the substantial demographic dynamics of Muslims in Europe, leading to the fact that Islam has become as the second largest religion in Europe in terms of the adherents' population (Buijs\&Rath, 2006; EUMC, 2006; Michaels, 2009; Savage, 2004;). The literature recognizes the lack of accurate and comprehensive demographic statistics on Muslims in Europe (e.g.,Buijs\&Rath, 2006; EUMC, 2006). For example, it has been asserted that 'the figures of Muslims living in Europe today are far from precise' (Buijs\&Rath, 2006). This has been partly explained by the fact that 'few European states have gathered comprehensive data on the number and nature of the Muslim presence within their national borders... Thirteen countries still do not recognize Islam as a religion ..." (Savage, 2004). Despite the lack of accurate and comprehensive statistics on the Muslim population in Europe, it is evidently documented in the literature that 'the Muslim population [in Europe] more than doubled in the last three decades, and the rate of growth is accelerating' (Savage, 2004:26). The rapidly growing population of Muslims in Europe is also documented in other studies (e.g.Buijs\&Rath, 2006; Jenkins, 2006; Martikainen, 2007). The report on Muslims in the European Union(EUMC, 2006:8) also acknowledges the inadequacy of demographic statistics on European Muslims and documents that 'the most conservative estimate based on official, where they are not available, unofficial data is of a Muslim population of around thirteen million, around 3.5 per cent of the total population of the European Union, but with great variations between the Member States'. The variations are also evident in Table 1 indicating the distribution of the Muslim population in Europe. According to this Table and as documented by Westoff and Frejka (2007), 'of the estimated 35-45 million Muslims in Europe, around 15 million reside in Western Europe, close to 8 million in Central and South-Eastern Europe, and between 15 and 20 million in the Russian Federation'.

The literature also identifies various stages regarding the settlement history of the Muslim population in Europe. The first stage started from the late 1940s (that is, after World War II) when Muslim residents of former colonial empires (largely from India, Caribbean, Indonesia, and Northern Africa) immigrated to Europe. This was accelerated in the following three decades as Europe needed more labour than their native population due to the post-war economic development. This caused the migration of young and working-age Muslims to Europe whose family members have also been later allowed to join them. In more recent decades (particularly since 1990s), many Muslims immigrated to Europe as refugees (Gurer, 2019; Yigit \& Tatch, 2017) and asylum seekers mainly from Bosnia and Herzegovina (due to 
the Balkan wars), Afghanistan, Somalia, Iran, Iraq, and Turkey (Bigagli, 2019; Buijs\&Rath, 2006; EUMC, 2006; Westoff \& Frejka, 2007). This settlement history of Muslims in Europe has also provided the following major consequences. First, the ethnic composition of European Muslims varies across the continent: Pakistanis and Indians constitute the majority of Muslims in the UK; the main source countries of German Muslims are Turkey and former Yugoslavia; French Muslims are largely Algerian, Moroccan, and Tunisian (Buijs\&Rath, 2006; Westoff\&Frejka, 2007). Second, since the majority of Muslims in Europe immigrated after World War II till the early 1970s, the present Muslim population in Europe are largely descendants of second and third generations. For example, about half of the Muslim population in Western Europe were born there (Malik, 2004). It has also been documented that almost 50 percent of UK Muslims in 2001 were British-born (Peach, 2006). Third, a more important demographic consequence refers to the age structure of present European Muslims which also substantially determines the projection of the Muslim population in the continent's future. For example, one-third of French Muslims are under the age of 20 (compared to 21 per cent of French population as a whole), one-third of German Muslims are under 18 (compared to 18 percent of the German population as a whole), and one-third of the UK Muslims are under 15 (compared to 20 percent of the British population as a whole) (EUMC, 2006; Savage, 2004). Further, the Muslim population usually hasa significantly higher level of fertility which is also true for Muslim women in Europe (Peach, 2006; Westoff\&Frejka, 2007). This is also an evident observation in Table 2. According to this Table, although TFR (i.e., the average number of children per woman) has decreased for all women (including Muslim women) in the selected European countries over time, Muslim women still have the highest level of fertility. Accordingly, the combination of these two key demographic characteristics of Muslim migrants (that is, younger age structure and higher birth rate) will lead to their higher contribution in shaping Europe's population composition in future which has also been entitled as 'the demographic time bomb' (Michaels, 2009). For example, the projection for Europe's population by 2015 shows that the population of non-Muslims will fall by at least 3.5 percent, whereas the Muslim population will double (Michaels, 2009; Savage, 2004). In Demographics, Religion, and the Future of Europe, Jenkins (2006) has also documented that Muslims will comprise about a quarter of Europe's population by 2100 , while presently,they constitute approximately 5 percent of the continent's population.

Table 1

Population of Muslims in Western Europe 2005 (in millions)

\begin{tabular}{lccc}
\hline Country & Muslim population & Total population & Percentage \\
\hline France & 5 & 60 & 8.3 \\
Germany & 3.5 & 82 & 4.3 \\
Britain & 1.6 & 60 & 2.7 \\
Italy & 1 & 57 & 1.8 \\
Spain & 1 & 41 & 2.4 \\
Netherlands & 1 & 16 & 6.3 \\
Belgium & 0.4 & 10.3 & 3.9 \\
Austria & 0.35 & 8 & 4.4 \\
Sweden & 0.33 & 9 & 3.7 \\
Switzerland & 0.31 & 7.2 & 4.3 \\
Denmark & 0.27 & 5.4 & 5.0 \\
Norway & 0.08 & 4.5 & 2.0 \\
\hline
\end{tabular}


Sources: Jenkins (2006:532): Demographics, Religion, and Future of Europe; Westoff and Frejka (2007:786): Religiousness and Fertility among European Muslims.

Note: It has also been noted that the population of Muslims in Eastern and Central Europe (including Kosovo, Albania, Bosnia and Herzegovina, Macedonia, Bulgaria, Serbia and Montenegro, Slovenia, Croatia, Hungary, and Romania) is about 7.2 millions and there are also 15-20 million Muslims in Russian Federation (Westoff\&Frejka (2007, p. 786).

Finally, the literature review also shows that with regard to the demographic status of Muslim migrants in Europe and in the United States, at least two key points can be addressed. First, the proportion of the Muslim population in Europe is smaller as compared with Muslims in Europe. Muslims contribute about 1 percent of the US total population or approximately three million people, as indicated in the existing literature (Foner and Alba 2008; Peach,2006). Further, the ethnic composition of the US Muslim population mainly includes South Asian (around a quarter), Arabs (about 12 percent), Africans (6 percent), Iranians (4 percent), and Turks ( 2 percent). Second, the literature also emphasises that immigrant religions, including Islam and Muslims, are more welcomed in the United States than in Western Europe, partly due to a higher level of 'the religiosity of the native population' of the former (Foner \& Alba, 2008).

Table 2

Total Fertility Rate (TFR), children ever born, and completed fertility (per woman), by religion: Austria, Bulgaria, Croatia, Slovenia, and Ukraine, 1981-2003

\begin{tabular}{llll}
\hline Religion & 1981 & 1991 & 2001 \\
\hline Roman Catholic & 1.70 & 1.52 & 1.32 \\
Protestant & 1.51 & 1.37 & 1.21 \\
Islam & 3.09 & 2.77 & 2.34 \\
Other religion & 1.70 & 1.61 & 1.44 \\
No religion & 1.12 & 1.04 & 0.86 \\
Total & 1.67 & 1.51 & 1.33
\end{tabular}

Sources:Westoff and Frejka (2007)

\section{The Field of Study}

As discussed before, the central focus of this paper is on Muslim migrants living in the multiethnic and multicultural context of Australia. It holds a substantial proportion of migrants who belong to a wide range of religions and cultures from throughout the world. Accordingly, this field of study operates as a 'human and social laboratory' to deal with the core objectives of the present analysis outlined in the previous section. Table 3 illustrates the major patterns regarding the place of religion in this multicultural context. Generally speaking, Christianity is the major religion: around two-third of the total population are Christians. Since the 1970s, multiculturalism was formally accepted as the government immigration policy. As a result, Australia has become the home of a wide range of religions from throughout the world (Buddhism, Hinduism, Judaism, Islam etc.). As illustrated in Table 3, the believers of Buddhism and Islam are the two largest religious minority groups in this country. Indeed, the adherents of Buddhism and Islam make up 6.3 and 5.1 percent respectively, of the Australian non-Christian 
population. Further, another important pattern refers to the phenomenon of 'no religion'. In accordance with the global pattern of secularization (Kaufman et al., 2012; van Tubergen, 2007; Voas, 2003), this phenomenon is also becoming overwhelmingly more visible over the time in this country: about one-fifth of population were affiliated to 'no religion' in 2006; the corresponding proportion was 16 percent in 2001. This pattern is partly associated with gender: the proportion 'no religion' is more prevalent among males than females. This accords with the existing knowledge, which identifies the fact that women tend to be more religious than men (Levitt, 1995; Millerand\& Stark, 2002; Pew Research Center, 2012). More importantly, the phenomenon of 'no religion' is strongly affected by age: the younger the age, the greater the proportion 'no religion'.

Table 3

Population Distribution by religious affiliation and gender in Australia, 2001, 2011

\begin{tabular}{|c|c|c|c|c|c|c|}
\hline \multirow{2}{*}{$\begin{array}{l}\text { Religious } \\
\text { affiliation }\end{array}$} & \multicolumn{3}{|c|}{2001} & \multicolumn{3}{|c|}{2011} \\
\hline & Male & Female & Total & Male & Female & Total \\
\hline Christianity & 67.2 & 71.3 & 69.3 & 59.1 & 64.1 & 61.6 \\
\hline Buddhism & 2 & 2 & 2 & 2.3 & 2.7 & 2.5 \\
\hline Islam & 1.6 & 1.4 & 1.5 & 2.4 & 2.1 & 2.2 \\
\hline Hinduism & 0.6 & 0.5 & 0.5 & 1.4 & 1.2 & 1.3 \\
\hline Judaism & 0.4 & 0.5 & 0.5 & 0.4 & 0.5 & 0.5 \\
\hline Other religion & 0.5 & 0.5 & 0.5 & 0.8 & 0.8 & 0.8 \\
\hline No religion & 17.3 & 14.3 & 15.8 & 24.3 & 20.7 & 22.5 \\
\hline Not stated & 10.4 & 9.5 & 9.9 & 9.3 & 8.0 & 8.6 \\
\hline Total & 100.0 & 100.0 & 100.0 & 100.0 & 100.0 & 100.0 \\
\hline Total number & 9068424 & 9348735 & 18417159 & 10524572 & 10808865 & 21333437 \\
\hline
\end{tabular}

Source: Computed from the Australian Bureau of Statistics (ABS): Censuses Data 2001, 2011

\section{Data and Methodology}

Data used in this paper are based on both descriptive and multivariate results of research conducted in the multiethnic and multicultural context of Australia. It particularly focuses on the status of immigrants whose 'religious affiliation' was indicated as 'Islam' (i.e., Muslim immigrants).The original database used in this analysis is customized tabulations from the 2001 Australian Census of Population and Housing 2 The tables are matrices of relevant variables cross-classified against each other. The matrix or cell data are converted to individual records in SPSS format. This large database deals with approximately 5.4 million women in the main working ages, of whom about 25 percent are overseas-born. It is also important to mention that

2 This is to acknowledge that this dataset is customized tabulations provided by The Australian Bureau of Statistics (ABS) for which I would also like to gratefully acknowledge the support of Professor Peter McDonald at The Australian Demographic and Social Research Institute (formerly, Demography \& Sociology Program), The Australian National University, Canberra, ACT, Australia. 
since the large database used in this study was initially provided to examine employment differentials, it considers people in working ages (15-54 years). Further, this study uses the method of logistic regression analysis. This statistical method is advantageous in this analysis because it provides the opportunity to examine the differentials both withinMuslim migrants by their ethnic origins and between Muslim and non-Muslim migrants while the competing determinants are held constant in the analysis. More specifically, this statistical technique is more appropriate and benefetial in such a type of studies in the multiethnic and multicultural context of Australia due to two key explanations: On the one hand, the Australian Muslims are overwhelmingly diverse by ethnic identity and contribute substantially diverse compositional characteristics influencing their performance in the labour market, including education, English skill, length of residence, family characteristics, age structure etc. (Foroutan, 2008a, 2015). On the other hand, the prior studies have also clearly indicated the fact that these characteristics influencing labour market performance are overwhelmingly correlated (e.g. Evans, 1984; Foroutan and McDonald, 2008; McCorkle, 2020; VandenHeuvel and Wooden, 1999;Wooden, 1994). This leads to the vital importance of using this statistical technique. Accordingly, the present anmalysis is also benefited to employ the statistical technique of logistic regression analysis, that examines the patterns and the differentials by religion while other competing determinants such as human capital, age, family and ethnic characteristics are held constant in the analysis.

In terms of the dependent and independent variables, this analysishas two major dependent variables: 'employment status' and 'occupational levels'. First, it looks at 'employment status' by which individuals are whether 'employed' (including employee, employer, own account worker, and contributing family worker) or 'not employed' (including unemployed looking for full-time/ part-time work, not in labour force). The second dependent variable is 'occupational levels' by which working individuals have been categorized in three major occupational levels: 'High occupations' (including professionals and associate professionals, managers, and administrators), 'Middle occupations' (including advanced clerical and service workers, intermediate clerical, sales and service workers, and elementary clerical, sales and service workers), and 'Low occupations' (including labourers and related workers tradespersons and related workers, intermediate production, and transport workers).On the other hand, the main independentvariables considered in the present analysis include the following determinants: migration status (whether 'migrant' or 'native-born'), religious affiliation (whether 'Muslim' or 'non-Muslim'), educational attainment ('high education' including postgraduate degree, graduate diploma and graduate certificate, bachelor degree, advanced diploma and diploma level; 'middle education' including Year 9-12 or equivalent, certificate level; and 'low education' including Did not go to school, year 8, or below), English proficiency ('Very well' including those who only speak English, Speak English very well; 'Well' including those who speak English well; and 'Not well' including those who speak English well).

\section{Settlement History of Muslim Migrants}

As mentioned above, this paper gives specific focus to the status of Muslim migrants. Accordingly, this section provides background information regarding the settlement history of the particular migrant groups of this study. In historical terms, there have been three major stages of contact of Muslims with Australia. The first stage had started before European settlement. From the seventeenth century, there was communication between Muslim Macassar fishermen in Indonesia and the Aboriginal people (Bouma, 1994;Cigler, 1986; Cleland, 2001; Foroutan, 2008b, 2009b, 2019a). Then, in the 19th century, Muslims largely from Afghanistan and India migrated to Australia with camels and played a key role in national projects including roads, dams, and railways (Cigler, 1986; Foroutan, 2011a, 2019a; Schinasi, 1980). This stage 
was followed by a hard period after The 1901 Immigration Restriction Act. Accompanied by substantial economic improvements, the settlement of Muslims entered a new period in the second part of the last century in multicultural Australia. On the whole, the vast majority of Muslims have migrated to Australia since 1971. Moreover, despite the fact that the Australian Muslim population is very diverse by birthplace, Turkish and Lebanese immigrants have constituted the highest proportion of Muslim population in Australia since 1971 (Bouma, 1994; Cigler, 1986; Cleland, 2001; Foroutan, 2009b, 2015). Muslim immigration to Australia is also partly due to political hardship, religious persecution, sectarian intolerance, and civil war in the homelands. For instance, around 4000 Lebanese Muslims came to Australia within first two years of the outbreak of the civil war in Lebanon in $1975(2009,2015)$ and the arrival of European Muslims after World War II was based on the bilateral agreement between the International Refugee Organisation and the Australian government in 1947 (Jones 1993). The population of Muslims in Australia increased markedly from about 22,000 in 1971 to approximately 280,000 in 2001, 340,000 in 2006, and almost 480,000 in the latest census in 2011 (ABS, 2006; Foroutan, 2011b, 2017;ABS, 2006, 2012). According to The Future of the Global Muslim Population (Pew Research Center, 2011), the population of Muslims in Australia will increase to 714,000 by 2030 which include almost $3 \%$ of the country's total population and will be almost $80 \%$ increase between 2010 and 2030 .

\section{Demographic Profile}

\section{Population and Ethnic Composition}

This section highlights the main demographic characteristics of Muslim migrants inthis study. As mentioned before, this study focuses particularly on the status of female Muslim migrants. According to the data illustrated in Table 4, the total population of Muslims included in this study is about 82,000. The majority of them are overseas-born (migrants) and the remaining are natives (Australian-born): approximately 75 and 25 percent, respectively. Although Muslim migrants included in this analysis are substantially diverse in terms of ethnic origin, their largest ethnic groups are Lebanese and Turkish who constitute about a quarter of the Muslim migrants of this study. The remaining major source countries of these Muslim migrants are Indonesia, Bosnia and Herzegovina, Afghanistan, Pakistan, Fiji, Bangladesh, Iran, Iraq, Malaysia, Somalia, Cyprus, and Egypt (See Figure 1). The detailed information is also presented in Table 5, which indicates the major individual country of birth within each region of origin. For instance, about half of Muslim migrants from South East Asia are Indonesians, and the majority of Muslim migrants from North Africa \& Middle East are Somalis, Egyptians, and Syrians.

Table 4

The population of Muslims and non-Muslims included in this study

\begin{tabular}{lccc}
\hline Migration status & Muslims & Non-Muslims & Total \\
\hline Migrants (Overseas-born) & 74.2 & 23.4 & 24.2 \\
Natives (Australian-born) & 23.0 & 72.4 & 71.7 \\
Not stated & 2.8 & 4.2 & 4.1 \\
Total & 100.0 & 100.0 & 100.0 \\
Frequency & 81,879 & $5,291,416$ & $5,373,295$ \\
\hline
\end{tabular}


Source: Computed from the Customized Tables from the 2001 Australian Census of Population and Housing (Australian Bureau of Statistics); Also, see the section of 'Data and Methodology' in this article.

Note: This table is obtained from a file, which is partly affected by the issue of confidentiality caused by a large number of cross tabulations and small numbers in the cells of Super Table. It also excludes those whose country of birth is 'not stated' or 'inadequately described'.

Table 5

Major individual Countries of Birth of Muslim Migrants by Ethnic Origin

\begin{tabular}{lclc}
\hline Region of origin & \% & Region of origin & $\%$ \\
\hline North Africa Middle East & 100.0 & Eastern Europe & $100.0(9.7)$ \\
Somalia & 22.1 & Bosnia \& Herzegovina & 60.6 \\
Egypt & 16.2 & FYROM (Macedonia) & 16.8 \\
Syria & 14.5 & Yugoslavia, Federal Republic & 11.8 \\
Others & 47.2 & Others & 10.8 \\
South East Asia & 100.0 & South Asia & $100.0(10.8)$ \\
Indonesia & 55.7 & Pakistan & 41.5 \\
Malaysia & 21.2 & Bangladesh & 36.8 \\
Singapore & 15.1 & India & 11.5 \\
Others & 8.0 & Others & 10.2 \\
Central \& North East Asia & 100.0 & Developed Countries & $100.0(2.2)$ \\
Afghanistan & 40.2 & United Kingdom & 32.9 \\
Iran & 28.3 & Western Europe & 18.4 \\
Iraq & 27.4 & New Zealand & 17.6 \\
Others & 4.1 & Others & 31.1 \\
Sub & 100.0 & Turkey, Cyprus, Greece & $100.0(17.8)$ \\
Polynesia [Fiji] & 64.9 & Turkey & 87.3 \\
South Africa & 19.4 & Cyprus & 11.5 \\
Mauritius & 2.2 & Greece & 1.2 \\
Others & 13.5 & Total (all regions of origin) & $(\mathbf{1 0 0 . 0})$ \\
\hline
\end{tabular}

Source: See Table 4.

Notes: (1) This table excludes those whose birthplace is 'Not stated'. It also keeps out those whose country of birth is 'Inadequately described'. (2) Note of Table 4 also applies to this table.

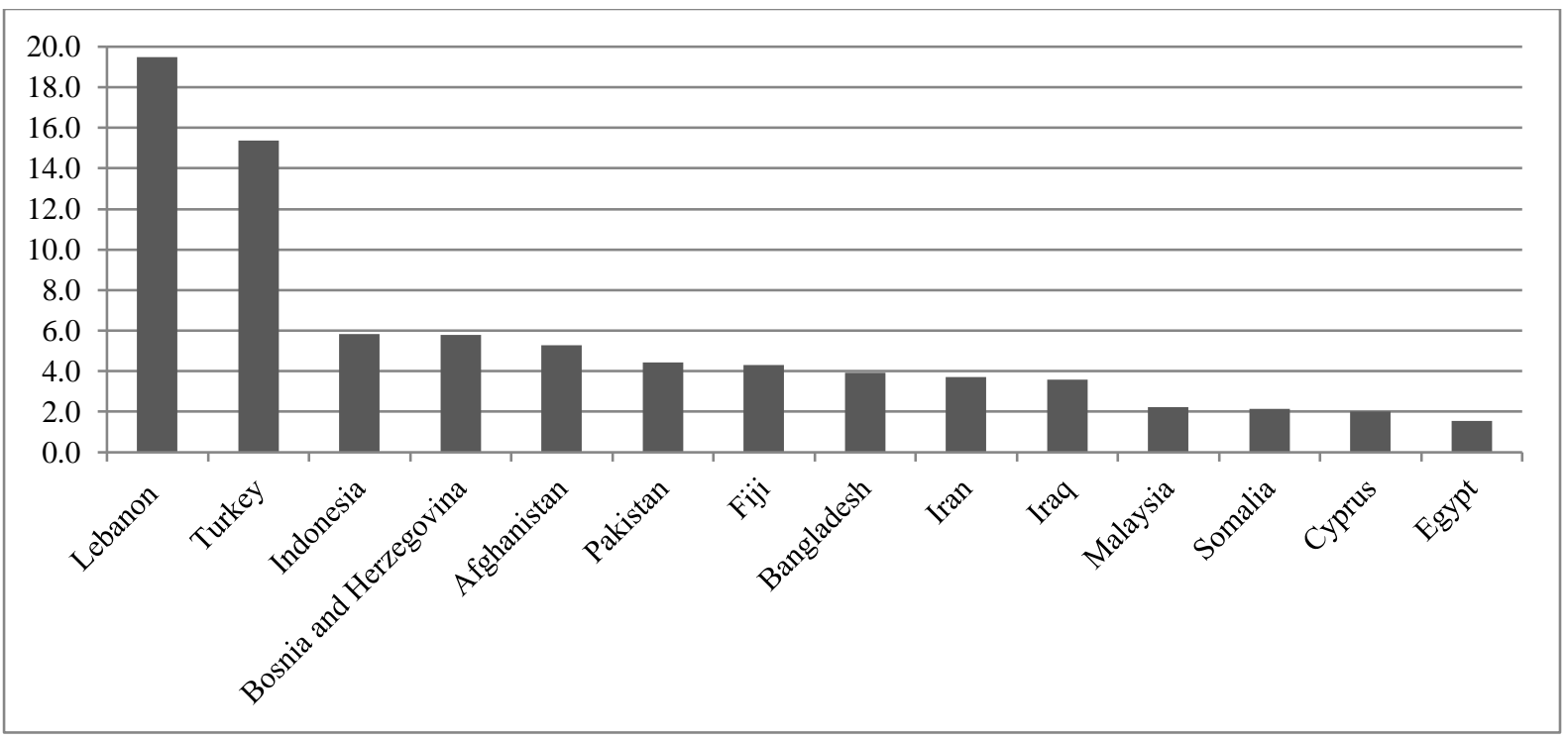

Figure 1. Major source countries (including 80 per cent) of Muslim migrants of this study 
Source: See Table 4

Note: Note of Table 4 also applies to this Figure.

\section{Socio-Demographic Characteristics}

Moreover, the key results of this study regarding Muslim migrants' characteristics such as age composition, educational attainment, English proficiency, and length of residence are illustrated in Table 6 and Figure 2. It is worthwhile to state that these characteristics are also considered as the most important determinants of migrants' status and success in the destination society. This is particularly the case for human capital endowments such as education and English proficiency. For instance,education has been assertedas a vehicle for socioeconomic mobility in the settlement andsuccess of migrants in the host country (Chiswick and Miller, 2010;Cob-Clark, 2003;Eggert et al. 2010;Foroutan, 2009c, 2013, 2017;Fuller and Martin, 2012; Hook and Balistreri, 2002; Kler, 2006; Silalahi \& Yuwono, 2018). According to the literature, English skill also operates as a key that opens the door to a wide range of socio-economic and cultural possibilities for migrants (Foroutan, 2008b, 2014;Kler, 2006; McAllister, 1986; Pichler, 2011; Robbins et.al.,2019). According to the data shown in Table 6 and Figure 2, the most important socio-demographic characteristics of Muslim migrants of this study are discussed here. Broadly speaking, about one-fifth of these Muslim migrants are highly educated, approximately 45 percent of them are highly proficient in the English language, and around half of them have lived in Australia for longer than 10 years.Furthermore, the detailed information provided in Table 6 and Figure 2 shows that these characteristics vary substantially among Muslim migrants in terms of their ethnic origins. For instance, while nearly half of South Asian Muslim migrants (largely from Pakistan, Bangladesh and India) are highly educated, the corresponding proportion for the two largest groups of Muslim migrants (i.e.,Lebanese and Turkish) is only 10 percent or less. In other words, the proportion of low educated Muslim migrants from Lebanon and Turkey is more than six times greater than the corresponding proportion for Muslim migrants from South Asia (i.e., roughly 35\% and 5\%, respectively).

Another example relates to the significant differences amongst Muslim migrants in terms of English proficiency across the regions of origin: the proportions of those highly proficient in the English language range from more than 80 percent among Muslim migrants from Sub-Saharan Africa, the Caribbean, Pacific Islands (mostly Fijians) and the developed countries (largely from the UK, Western Europe, and New Zealand), to less than 40 percent among Turkish, Eastern European (largely from Bosnia and Herzegovina), Lebanese, and Central and Northeast Asian Muslim migrants (mainly from Afghanistan, Iran, and Iraq). Further, substantial differences amongst Muslim migrants across the regions of origin are also observed in other characteristics influencing the status and success of migrants (see Table 6 and Figure 2).

This is also a very important and visible observation for the duration of residence in Australia: on the high end, Muslim migrants from Lebanon and Turkey are the longest-term residents such that the majority of them (about 80 percent) have lived in Australia for more than tenyears. The corresponding proportion is also relatively high for Muslim migrants from the developed countries: about 65 percent have lived in Australia for more than tenyears. On the low end, the data provided in Table 6 and Figure 2 indicates that the remaining ethnic groups of Muslim migrants are relatively recent migrants such that the majority of them have lived in Australia for tenyears or less. This particularly applies to Muslim migrants from Central and Northeast Asia and to South Asian Muslim migrants: more than 70 percent of them have lived in Australia for tenyears or less. It is worthwhile to mention that the duration of residence has also been identified as a key determinant of migrants' status and success in the new society upon migration. According to a large body of literature,length of residence in the destination 
country operates as a leading facilitator ofsettlement and assimilation of immigrants so that the status and success of migrants has been observed mainly as 'a matter of time' (e.g.,Adsera and Chiswick, 2007;Evans, 1984; Friedberg, 2000; Foroutan, 2008e, 2011a, 2019b; Khoo and McDonald, 2001; Kossoudji,1989; Hirschman, 1994; VandenHeuvel and Wooden, 1996, 1999; Wooden, 1994).

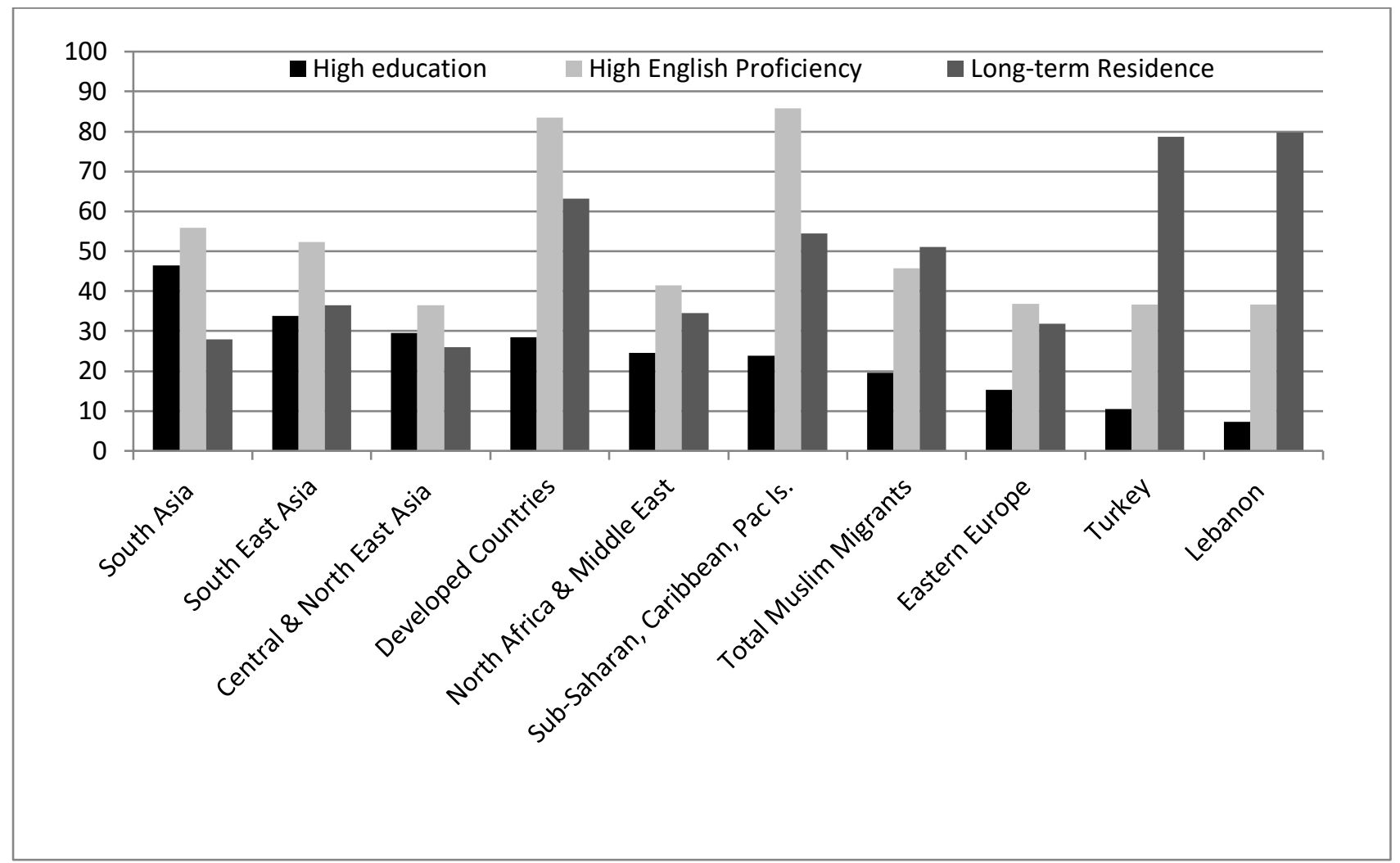

Figure 2. Percentage of Muslim migrants 'highly educated', 'highly proficient in English', and 'long-term residents' by ethnic origin

Source: See Table 4

Note: (1) Note of Table 4 also applies to this Figure.

\section{Table 6}

Demographic Characteristics of Muslim migrants of this study by ethnic origin

\begin{tabular}{|c|c|c|c|c|c|c|c|c|c|}
\hline Characteristics & $\begin{array}{c}\text { Total } \\
\text { Muslim } \\
\text { Migrants }\end{array}$ & $\begin{array}{l}\text { Central, } \\
\text { North East } \\
\text { Asia }\end{array}$ & $\begin{array}{l}\text { Developed } \\
\text { Countries }\end{array}$ & $\begin{array}{l}\text { Eastern } \\
\text { Europe }\end{array}$ & Lebanon & $\begin{array}{c}\text { North } \\
\text { Africa, } \\
\text { Middle } \\
\text { East }\end{array}$ & $\begin{array}{c}\text { South } \\
\text { Asia }\end{array}$ & $\begin{array}{c}\text { Southeast } \\
\text { Asia }\end{array}$ & $\begin{array}{l}\text { Turkey, } \\
\text { Cyprus, } \\
\text { Greece }\end{array}$ \\
\hline
\end{tabular}

Age groups

$\begin{array}{llllllllll}\text { 15-24 years } & 30.8 & 27.7 & 31.4 & 19.3 & 15.4 & 26.1 & 20.7 & 25.7 & 10.5 \\ \text { 25-34 years } & 30.2 & 30.6 & 34.4 & 26.8 & 30.7 & 34.2 & 37.8 & 33.0 & 33.2 \\ 35-44 \text { years } & 24.3 & 27.1 & 21.8 & 32.7 & 32.5 & 25.2 & 29.7 & 25.4 & 32.6 \\ 45-54 \text { years } & 14.7 & 14.6 & 12.4 & 21.2 & 21.4 & 14.5 & 11.8 & 15.9 & 23.7\end{array}$

Education

$\begin{array}{lccccccccc}\begin{array}{l}\text { High } \\ \text { education }\end{array} & 19.6 & 29.6 & 28.5 & 15.3 & 7.2 & 24.5 & 46.5 & 33.8 & 10.5 \\ \begin{array}{l}\text { Middle } \\ \text { education }\end{array} & 56.9 & 51.2 & 62.9 & 53.4 & 58.2 & 52.6 & 45.1 & 55.2 & 49.6 \\ \begin{array}{l}\text { Low } \\ \text { education }\end{array} & 16.5 & 12.9 & 3.3 & 25.3 & 32.4 & 15.6 & 4.8 & 7.2 & 37.4\end{array}$




\begin{tabular}{|c|c|c|c|c|c|c|c|c|c|}
\hline Still at school & 7.0 & 6.3 & 5.3 & 6.0 & 2.2 & 7.3 & 3.6 & 3.8 & 2.5 \\
\hline \multicolumn{10}{|l|}{$\begin{array}{l}\text { English } \\
\text { proficiency }\end{array}$} \\
\hline Very well & 45.8 & 36.5 & 83.5 & 36.8 & 39.7 & 41.4 & 55.8 & 52.4 & 36.6 \\
\hline Well & 31.6 & 34.4 & 11.5 & 36.6 & 31.2 & 36.3 & 33.5 & 37.3 & 29.1 \\
\hline Not well & 22.6 & 29.1 & 5.0 & 26.6 & 29.1 & 22.3 & 10.7 & 10.3 & 34.3 \\
\hline \multicolumn{10}{|l|}{$\begin{array}{l}\text { Length of } \\
\text { residence }\end{array}$} \\
\hline 10 years + & 51.0 & 26.0 & 63.2 & 31.9 & 79.8 & 34.6 & 28.0 & 36.4 & 78.6 \\
\hline 10 years or less & 49.0 & 74.0 & 36.8 & 68.1 & 20.2 & 65.4 & 72.0 & 63.6 & 21.4 \\
\hline
\end{tabular}

Source: See Table 4.

Note: (1)This table excludes those whose education, English proficiency, year of arrival in Australia, birthplace and employment status is 'not stated'. (2) Note of Table 4 also applies to this Table.

\section{Preliminary Results}

This section presents the preliminary results of this study regarding the employment patterns of Muslim migrants. It is worthwhile to mention thatemploymenthas been identified as 'the most important determinant of a person's living and lifestyle' (Collins, 1988:162) and as a key indication of migrants' settlement and integration process in the host country (Alba and Nee, 2005;Bouma, 1994; Foroutan, 2008d,2017; Gilbertson, 1995; Jacobsen Koepke et.al., 2019; Pichler, 2011; VandenHeuvel and Wooden, 1996, ). The discussion of this section is based on the results of the present study illustrated in Figure 3. According to Figure3, broadly speaking, less than one-third of Muslim migrants are 'employed'. More clearly, the proportion 'employed' for Muslim migrants is about 28 percent. The corresponding proportion for total Muslims (including both migrants and natives) is about 31 percent. Furthermore, the research results illustrated in Figure 3 show that the employment status of Muslim migrants is strongly associated with their ethnic backgrounds. On the one hand, more than half of Muslim migrants from Sub-Sahara, Caribbean, Pacific Islands (mostly Fijians), and about 45 percent of Muslim migrants from developed countries (largely from the UK, Western Europe, and New Zealand) are employed. Also, one-third of Muslim migrants from South Asia (mainly Pakistanis, Bangladeshis, and Indians), Eastern Europe (largely from Bosnia and Herzegovina), South East Asia (mainly Indonesians and Malaysians), as well as native (i.e. Australian-born) Muslims, are 'employed'. On the other hand, the proportion 'employed' is substantially lower for Muslim migrants from the remaining regions of origin. This particularly applies to Muslim migrants from the North Africa \& Middle East (mostly from Somalia, Egypt, and Syria) and from Lebanon: less than one-fifth of them are employed. The corresponding proportion is also relatively low for Muslim migrants from Central, North-East Asia (mainly from Afghanistan, Iran, and Iraq): that is, about 25 percent.

Moreover, Figure 3 presents the results of this study with respect to the occupational levels of employed Muslim migrants. Generally speaking, about a quarter of employed Muslim migrants work in high-level occupations (that is, professionals and managers). The corresponding proportion for both native-born and total Muslims (migrants and natives) is slightly greater: about 30 percent of them work in professional and managerial jobs. However, the results of this study illustrated in Figure 3 show that these occupational characteristics are also markedly subject to the ethnic backgrounds of Muslim migrants. On the high end, more than 40 percent of Muslim migrants fromNorth Africa \& Middle East are employed in 
professional and managerial occupations. The corresponding proportion is also relatively high for Muslim migrants from the developed countries (largely from the UK, Western Europe and New Zealand) and for Central and Northeast Asian Muslim migrants (mainly from Afghanistan, Iran and Iraq): that is, about 38 percent. On the low end, a substantially lower proportion of Muslim migrants from some of the other regions of origin work in professional and managerial occupations. This particularly applies to Eastern European Muslim migrants: only 17 percent of them work in high-level jobs. The corresponding proportion is also relatively low for Muslim migrants from South East Asia and Turkey: only about a quarter of them are employed in professional and managerial occupations (See Figure 3).

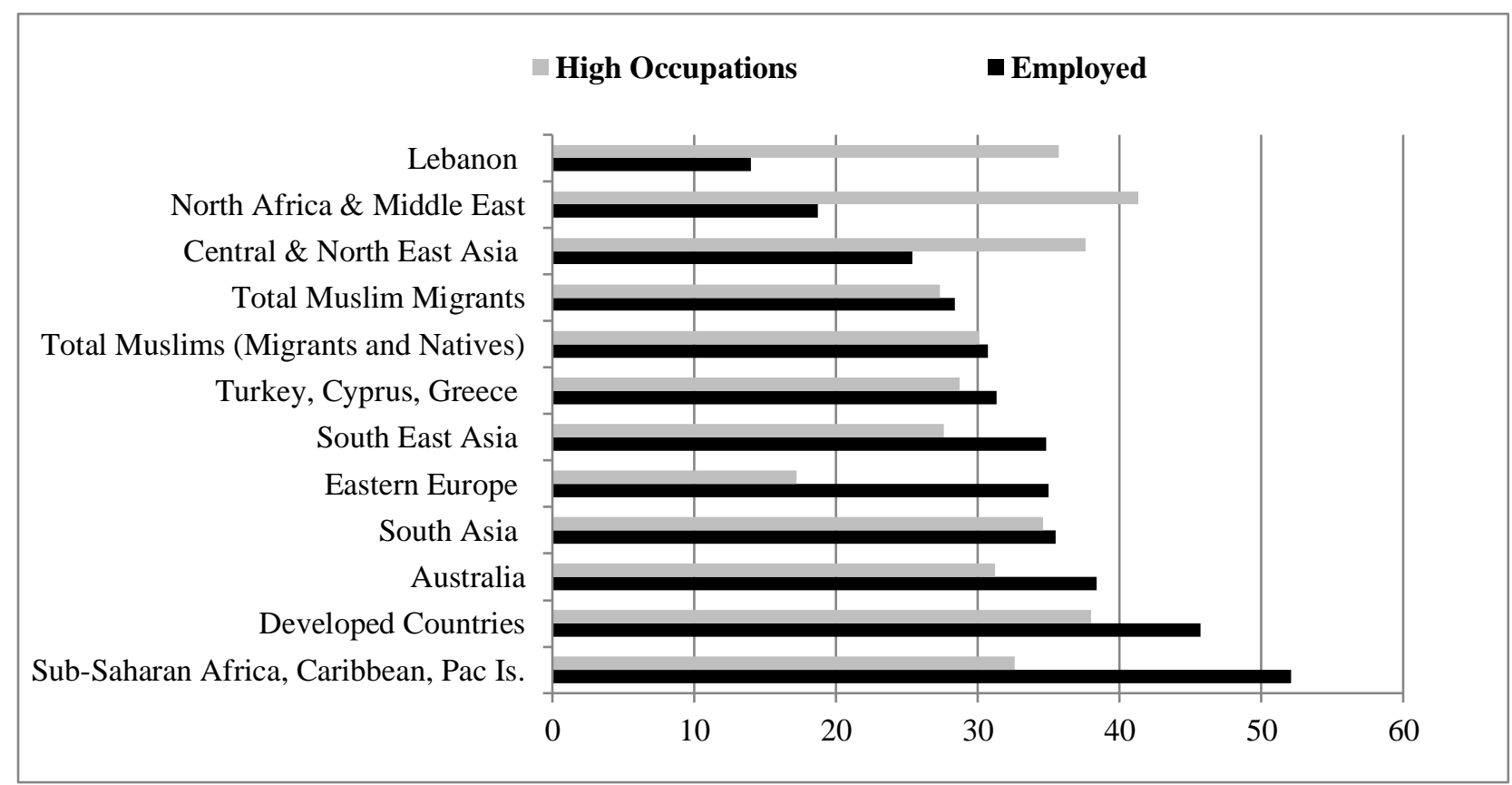

Figure 3. Percentage 'employed' and 'working in high occupations' for Muslims of this study by ethnic origin

Source: See Table 4.

Note: (1) Note of Table 4 also applies to this figure.

\section{Multivariate Findings}

It is acknowledged that the descriptive results highlighted in the previous section regarding the work patterns of Muslim migrants can be affected by varying socio-demographic determinants. This tends to be particularly the case for Muslim migrants of this study because, as explained before, they hold overwhelmingly varying compositional characteristics by their ethnic origins. Accordingly, this section uses the multivariate results of the present study. These results are based on logistic regression analysis. It highlights work patterns and differentials of Muslim migrants while simultaneously controlling for other competing determinants included in the models. This refers to determinants such as educational level, English competency, age composition, duration of residence, family characteristics (including whether or not partnered, household's income, presence of a child at home, and age of the youngest child). Accordingly, these multivariate findings canprovide more accurate information. The multivariate findings of this study are illustrated in Figure 4. This Figureindicates the work differentials among Muslim and non-Muslim migrants from the same region/country of origin. According to this Figure, there is a wide range of patterns in this regard. This means that the differentials among Muslim and non-Muslim migrants are substantially associated with their ethnic origins representing 
varying socio-cultural backgrounds. For instance, a typical pattern relates to migrants from Lebanon and the North Africa \& Middle East: among them, non-Muslim migrants are more than twice as likely as Muslim migrants to be employed. This also tends to be a substantial gap for migrants from South East Asia, and from Central \&North East Asia, meaning that nonMuslim migrants are significantly more likely to be employed than Muslim migrants from these Asian regions. The opposite applies to some other groups of migrants. This is more evidently the case for migrants from Eastern Europe and Sub-Saharan Africa, Caribbean, and Pacific Islands: among migrants from these two main regions of origin, Muslim migrants are almost as likely as non-Muslim migrants to be employed.

Moreover, the results of this study illustrated in Figure 4with respect to the probability of working in high-level occupations (that is, professionals and managers) for migrants by their religious affiliation indicate two main patterns. (1) Broadly speaking, the occupational differentials among these two religious groups of migrants (that is, Muslim and non-Muslim migrants) are slight. (2) More specifically, there are totally different patterns regarding occupational differentials of migrants by their religious affiliation: in some cases, the probability of working in professional and managerial occupations is relatively greater for Muslim migrants than for non-Muslim migrants, whereas the opposite exists in some other cases. For example, among migrants from Lebanon and North Africa \& Middle East, Muslim migrants are slightly more likely than non-Muslim migrants to be employed in professional and managerial occupations. The opposite applies to other migrant groups. However, it is also important to mention that among the latter, the degree of occupational differentials among these two religious groups of migrants is also subject to their ethnic origins. For instance, among migrants from Eastern Europe and developed countries, the greater probability of working in professional and managerial occupations for non-Muslim migrants (compared with Muslim migrants) is relatively more significant. On the other hand, this relatively greater probability for non-Muslim migrants from South East Asia and Turkey (relative to Muslim migrants from the same regions of origins) is so insignificant that it could be ignored.

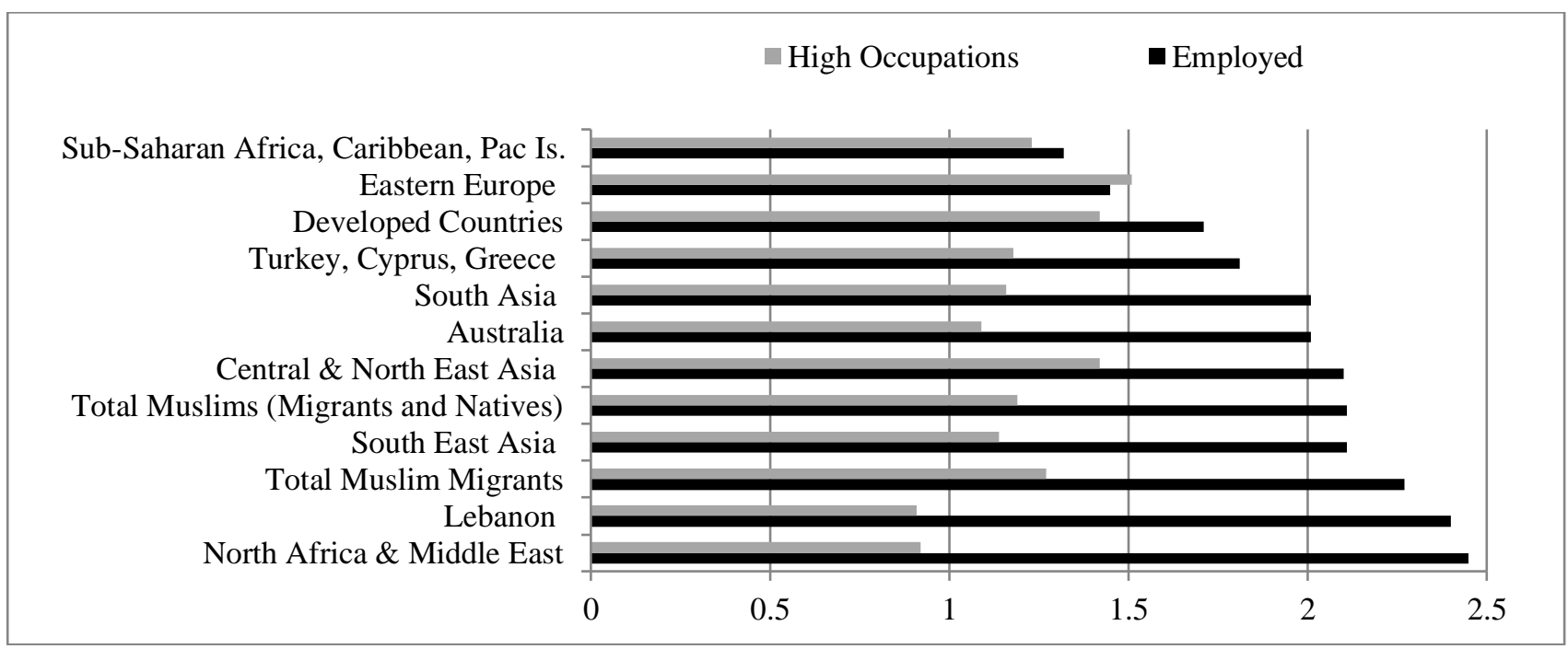

Figure 4. Multivariate results indicating the likelihood of 'being employed' and 'working in professional and managerial occupations' for non-Muslims relative to Muslims (odds ratios)

Source: See Table 4.

Notes: (1) In employment status, 'employed' is coded as 1 (one) and 'not employed' is coded as 0 (zero) and the numbers (odds ratios) show the likelihood of being 'employed' for each category of non-Muslim migrants relative to the reference group (that is, Muslim migrants). (2) 
In occupational levels, 'working in high occupations' (professionals and managers) is coded as 1 (one) and 'working not in high occupations' (that is, other occupations) is coded as 0 (zero) and the numbers (odds ratios) show the likelihood of working in the 'high occupations' for each category of non-Muslim migrants relative to the reference group (that is, Muslim migrants). (3) Note of Table 4 also applies to this figure.

\section{Concluding Remarks}

Focusing on the status of Muslim migrants, this paper has presented research-based evidence to shed further light on the existing knowledge about immigrants' religion. It has used customized data of population census, which also provides unique nation-wide data sources on 'religious affiliation'. The study has particularly focused on migrants in the multiethnic and multicultural context of Australia, whose religious affiliation was 'Islam' (that is, Muslim migrants). This multicultural field of study and its particular focus group have provided the opportunity to examine whether and to what extent data on migrants' religion could be reliable. This mainly lies in the fact that while the religious affiliation of all of these migrants is identified under the same category (i.e.,Islamand as Muslim migrants), they are overwhelmingly diverse in terms of ethnic origins from throughout the world representing various socio-cultural settings: Middle East \& North Africa, Asian regions, Eastern Europe, developed countries, the Pacific etc.

This study has supported an underlying point: the results on Muslim migrants as a single group differ substantially from the results based on their ethnic backgrounds. The sociodemographic characteristics highlighted in this paper have clearly shown that the contribution of human capital endowments, for instance, among Muslim migrants varies markedly across the regions of origin. The results have also indicated that there is not merely one single work pattern among these migrants who share Islam as their religious affiliation. Instead, they hold anextensive variety of work patterns based on their ethnic origins. I acknowledge that these patterns and differentials could be explained from various angles; however, these plausible explanations are beyond the scope of this paper3The underlying intention here has been to present empirical evidence to emphasise this bottom-line conclusion: studies on migrants' religion must consider the key point that migrants under the same category of religious affiliation are not necessarily a single group, but they must bestudiedby ethnic origins in order to avoid providing insufficient, incomplete, and misleading knowledge in our populationrelated studies and demographic research.

\section{References}

Addai-Mununkum, R. (2019). Students' representation of "other" religions. Journal Of Curriculum Studies Research, 1(1), 1-16. https://doi.org/10.46303/jcsr.01.01.

Adhikari R (2001). 'Muslims', IN: The Australian People: An Encyclopedia of the Nation, Its People, and Their Origins, Ed: J. Jupp, Cambridge University Press, Pp. 599-601.

Adsera, A., \& Chiswick, B. R. (2007) "Are there Gender and Country of Origin Differences in Immigrant Labor Market Outcomes across European Destinations?" Journal of Population Economics 20:495-526. DOI:https://doi.org/10.1007/s00148-006-0082-y.

Alba, R. \& Nee, V. (2005). Remaking the American mainstream: assimilation and contemporary immigration, Cambridge, MA and London: Harvard University Press.

3The plausible explanations for these socio-demographic and economic differentials mainly associated with the reasons and types of migration (including cultural integrationand socialization explanations, disadvantage and discrimination hypothesis, skilled migration program, humanitarian and refugee program, family reunion, etc.) have been widely discussed in my other works (Foroutan, 2008a,b,c,d,e, 2009a,b,c, 2011a,b, 2017, 2019a,b). 
Australian Bureau of Statistics (2001): Censuses of Population and Housing 2001, Australian Bureau of Statistics (ASB).

Australian Bureau of Statistics (2006): Censuses of Population and Housing 2006, Australian Bureau of Statistics (ASB).

Australian Bureau of Statistics (2011): Censuses of Population and Housing 2011, Australian Bureau of Statistics (ASB).

Berry, J. W. (1992). 'Acculturation and Adaptation in a New Society', International Migration, Vol. xxx, Special Issue: Migration and Health in the 1990s. Pp. 69-101. DOI: https://doi.org/10.1111/j.1468-2435.1992.tb00776.x

Bevelander, P. (2005) The employment status of immigrant women: the case of Sweden, International Migration Review 39 (1): 173-202. DOI:https://doi.org/10.1111/j.17477379.2005.tb00259.x

Bigagli, F. (2019). School, ethnicity and nation-building in post-colonial Myanmar. Research in Educational Policy and Management, 1(1), 1-16. https://doi.org/10.46303/repam.01.01.1

Bouma, G. D. (1994) Mosques and Muslim Settlement in Australia, Australian Government Publishing Service, Canberra, Australia.

Buijs, F.J. \& Rath, J. (2006), Muslims in Europe: The state of research, Amsterdam: University of Amsterdam.

Chiswick, B. R. \& Miller, P. W. (2010). The effects of educational-occupational mismatch on immigrant earning in Australia, with international comparisons, International Migration Review 44(4): $\quad 869-898$. DOI:https://doi.org/10.1111/j.17477379.2010.00829.x

Cigler, M. (1986). The Afghans in Australia, Australian Educa Press Pty Ltd, Melbourne.

Cleland, B. (2001). 'The History of Muslims in Australia', IN: Muslim Communities in Australia, Ed: A Saeed and S Akbarzadeh, University of New South Wales Press, Australia.

Cob-Clark, D. A. (2003). 'Public policy and the labor market adjustment of new immigrants to Australia", Journal of Population Economics 16: 655-681. DOI: 10.1007/s00148-0030153-2

Collins, J. (1988). Migrant Hands in a Distant Land: Australia's Post-War Immigration, Pluto Press, Sydney and London. DOI: https://doi.org/10.1080/12259276.2008.11666047

Eggert, W. et al. (2010). Education, unemployment and migration, Journal of Public Economics, 94: 354-362. DOI:https://doi.org/10.1016/j.jpubeco.2010.01.005

EUMC (European Monitoring Centre on Racism and Xenophobia). (2006). Muslims in the European Union: Discrimination and Islamophobia, EUMC.

Evans, M. D. R. (1984). Immigrant women in Australia: resources, family, and work. International Migration Review, 18(4), 1063-1090.

Foner, N. \& Alba, R. (2008). Immigrant religion in the U.S. and Western Europe: Bridge or barrier to inclusion?, International Migration Review, 42 (2): 360-392. DOI: 10.1111/j.1747-7379.2008.00128.x

Foroutan, Y . (2019a). Cultural analysis of Half-Century Demographic Swings of Iran: The Place of Popular Culture. Journal of Ethnic and Cultural Studies, 6 (1): 7789.DOI: http://dx.doi.org/10.29333/ejecs/184.

Foroutan, Y. (2008e). Employment Differentials of Second Generation Muslim Migrants: Assimilation and Discrimination Hypotheses. Immigrants \& Minorities, 26 (3): 219241.DOI: https://doi.org/10.1080/13602004.2011.599541. 
Foroutan, Y. (2009b). Gender and Religion:The Status of Women in the Muslim World. The World's Religions: Continuities and Transformations, edited by Peter Clarke and Peter Beyer, London and New York: Routledge Publication, pp. 223-235.

Foroutan, Y. (2011a). Ethnic and Religious Discrimination?: Multicultural Analysis of Muslim Minorities in the West. Journal of Muslim Minority Affairs, 31 (3): 327338.DOI:https://doi.org/10.1080/13602004.2011.599541.

Foroutan, Y. (2014). Social Change and Demographic Response in Iran (1956-2006). British Journal of Middle Eastern Studies, 41 (2): 219-229. DOI:https://doi.org/10.1080/13530194.2014.884317.

Foroutan, Y. (2015). Misunderstood Population?: Methodological Debate on Demography of Muslims in the West. Yearbook of International Religious Demography, The Netherlands: Brill Press.

Foroutan, Y. (2019b). Formation of Gender Identity in the Islamic Republic of Iran: Does Educational Institution Matter? Journal of Beliefs \& Values: Studies in Religion \& Education, 39 (2): 1-18.DOI:https://doi.org/10.1080/13617672.2018.1435087

Foroutan, Y. (2008a). Migration Differentials in Women's Market Employment: An Empirical and Multicultural Analysis. International Migration Review, 42 (3): 675-703. DOI:https://doi.org/10.1111/j.1747-7379.2008.00142.x.

Foroutan, Y. (2008b). Asian Migrant Women's Employment Participation: Patterns, Determinants and Differentials. Asian Journal ofWomen's Studies 14(2)109141.DOI: 10.1080/12259276.2008.11666047.

Foroutan, Y. (2008c). Gender, Religion and Work: Comparative Analysis of South Asian Migrants. Fieldwork in Religion, 3 (1): 29-50.DOI: 10.1558/firn.v3i1.29.

Foroutan, Y. (2008d). South Asian Female Migrants' Work Differentials: Multicultural Assessment. South Asia Research, 28 (2): 203224.DOI: $10.1177 / 026272800802800205$.

Foroutan, Y. (2009a). Religion, Migration and Social Change: Christian-Muslim Differentials. Australian Religion Studies Review, 22 (3): 295-319.DOI: 10.1558/arsr.v22i3.295

Foroutan, Y. (2009c).Migration and Gender Roles: Typical Work Pattern of the MENA Women. International Migration Review, 43 (4): 974-992.DOI:https://doi.org/10.1111/j.17477379.2009.00791.x.

Foroutan, Y. (2011b). Multiculturalism and Women's Employment: Sociological Perspective. New Zealand Sociology, 26 (1): 122-142.

Foroutan, Y. (2013). Family-Work Dilemma of Female Migrants: Patterns and Strategies. $\begin{array}{lllll}\text { Migration and } & \text { Development, } & 2 & \text { (2): } & \text { 1-19. }\end{array}$ DOI:https://doi.org/10.1080/21632324.2013.808412.

Foroutan, Y. (2017). Muslim Minority of New Zealand in Global Context: Demographic Perspective. Journal of Muslim Minority Affairs, 37 (4): 511-519. DOI:https://doi.org/10.1080/13602004.2017.1399599.

Foroutan, Y., \& McDonald, P. (2008). Asian Migrant Women's Employment Participation: Patterns, Determinants and Differentials. Asian Journal ofWomen's Studies, 14 (2): 109141

Friedberg, R. M. (2000). You Can't Take It with You? Immigrant Assimilation and the Probability of Human Capital. Journal of Labour Economics, 18 (2): 221-251.DOI: 10.1086/209957

Fuller, S., \& Martin, T. F. (2012). Predicting immigrant employment sequences in the first years of settlement. International Migration Review, $46 \quad$ (1): 138190. DOI: https://doi.org/10.1111/j.1747-7379.2012.00883.x.

Gilberston, G. A. (1995). Women's Labor and Enclave Employment: The Case of Dominican and Colombian Women in New York City. International Migration Review, 29 (3): 657 670. DOI: https://doi.org/10.1177/019791839502900302. 
Gregory, R. G. (2002). Can this be the promised land? Work and welfare for the modern women. Notes to Accompany the National Institutes Public Lecture, Canberra, Parliament House.

Gurer, C. (2019). Refugee Perspectives on Integration in Germany. American Journal of Qualitative Research, 3(2), 52-70. https://doi.org/10.29333/ajqr/6433.

Hirschman, C. (1994). Problems and Prospects of Studying Adaptation from the 1990 Population Census. International Migration Review, Vol. 28, Issue 4, Pp. 690-713. DOI: https://doi.org/10.1177/019791839402800404.

Hook, J. V., \& Balistreri, K. S. (2002). Diversity and Change in the Institutional Context of Immigrant Adaptation: California Schools 1985-2000. Demography 39 (4): 639-654. DOI:10.1353/dem.2002.0042.

Jacobsen Koepke, D., Thomas, D., \& Manning, A. (2019). Fatal Encounters. Research in Social Sciences and Technology, 4(1), 30-50. https://doi.org/10.46303/ressat.04.01.2

Jenkins, P. (2006). Demographics, religion, and the future of Europe. Elsevier Limited on behalf of Foreign Policy Research Institute: 519-539.

Jones, M. L. (1993). To Build What Was Lost: The Post-war Years and Beyond. An Australian Pilgrimage: Muslims in Australia from the Seventeenth Century to the Present, Ed: M L Jones, Melbourne: Victoria Press, Pp. 87-104.

Kaufmann, E., Goujon, A., \& Skirbekk, V. (2012). The end of secularization in Europe?: A socio-demographic perspective. Sociology of Religion, 73(1), 69-91.

Khoo, S. E., \& McDonald, P. (2001). Settlement Indicators and Benchmarks. Report Submitted to the Department of Immigration and Multicultural Affairs, Australia.

Kler, P. (2006). Graduated over-education and its effects among recently arrived immigrants to Australia: A longitudinal survey. International Migration 44(5): 93128.DOI: 10.1111/j.1468-2435.2006.00388.x.

Kossoudji, S. A. (1989). Immigrant Worker Assimilation: Is It a Labor Market Phenomenon?. The Journal of Human Resources, 24 (3): 494-527. DOI: 10.2307/145825

Krynski, A. (2019). In a State of Fragility: The Compromised Dignity of Communities, Indignation, and the Incapacitation of Public Education. Journal of Culture and Values in Education, 2(3), 1-24. https://doi.org/10.46303/jcve.03.02.1

Levitt, M. (1995). Sexual identity and religious socialization. The British journal of Sociology, 46(3): 529-536. DOI: https://doi.org/10.2307/591855.

Malik, J. (2004). Muslims in Europe: From the Margin to the Centre, LIT Berlin, Münster.

Martikainen, T. (2007). The governance of Islam in Finland. The Finish Society for the Study of Religion, 43 (2): 109-131. DOI: https://doi.org/10.33356/temenos.7914.

McAllister, I. (1986).Speaking the Language: Language Maintenance and English Proficiency among Immigrant Youth in Australia. Ethnic and Racial Studies, Vol. 9, Pp. 24-42. DOI: https://doi.org/10.1080/01419870.1986.9993513

McCorkle, W. D. (2020). The Relationship Between Teachers' Grade Level and Views on Immigration and Immigrant Students. Journal of Social Studies Education Research, 11(1), 21-41. Retrieved from https://jsser.org/index.php/jsser/article/view/1771

Michaels, A. (2009). Muslim Europe: the demographic time bomb transforming our continent. Telegraph, 08 August.

Miller, A. S., \& Stark, R. (2002). Gender and religiousness: Can socialization explanations be saved?. American Journal of Sociology, $107 \quad$ (6): 13931423.DOI: https://doi.org/10.1086/342557

Peach, C. (2006), Muslims in the 2001 Census of England and Wales: Gender and economic disadvantage. Ethnic and Ratial Studies, 26 (4): 629-655. DOI: https://doi.org/10.1080/01419870600665284 
Pew Research Center. (2011). The Future of the Global Muslim Population: Projections for 2010-2030. Pew Forum on Religion \& Public Life. January 2011.

Pew Research Center. (2012). Trends in American Values: 1987-2012. Retrieved from http://www.people-press.org/2012/06/04/partisan-polarization-surges-in-bush-obamayears/

Pichler, F. (2011). Success on European labor markets: a cross-national comparison of attainment between immigrant and majority populations. International Migration Review, 45 (4):938-978. DOI: https://doi.org/10.1111/j.1747-7379.2011.00873.x

Robbins, C., Bishop, J., \& Tarman, B. (2019). Against Reactionary Populism: Opening a Needed Conversation in Education. Journal of Culture and Values in Education, 2(3), i-vi. https://doi.org/10.46303/jcve.03.02.ed

Saktanber, A. (1991). Muslim identity in children's picture-books. IN: Islam in modern Turkey, edited vby R. Tapper, pp. 171-188.

Savage, T. (2004). Europe and Islam: Crescent waxing, cultures clashing. The Washington Quarterly, 27 (3): 25- 50. DOI: https://doi.org/10.1162/016366004323090241

Schinasi, M. (1980). The Afghans in Australia. The Afghanistan Forum, INC. New York.

Silalahi, R., \& Yuwono, U. (2018). The Sustainability of Pancasila in Indonesian Education System. Research in Social Sciences and Technology,3(2), 58-78. https://doi.org/10.46303/ressat.03.02.4

van Tubergen, F. (2007). Religious affiliation and participation among immigrants in a secular society: A study of immigrants in the Netherlands. Journal of Ethnic and Migration Studies, 33 (5): 747-765. DOI: https://doi.org/10.1080/13691830701359181

Vanden Heuvel, A., \& Wooden, M. (1996). Non-English Speaking Background Immigrant Women and Part-Time Work. Australian Government Publishing Service, Canberra, Australia.

Vanden Heuvel, A., \& Wooden, M. (1999). New Settlers Have Their Say. Department of Immigration and Multicultural Affairs, Australia.

Voas, D. (2003). Intermarriage and the demography of secularization. British Journal of Sociology, 54 (1): 83-108. DOI: https://doi.org/10.1080/0007131032000045914

Voas, D. (2009). The rise and fall of fuzzy fidelity in Europe. European Sociological Review, 25 (2): 155-168. DOI: https://doi.org/10.1093/esr/jen044

Westoff, C. F. \& Frejka, T. (2007). Religiousness and fertility among European Muslims. Population and Development Review, 33 (4): 785-809.DOI: 10.1111/j.17284457.2007.00197.x.

Wilder, L. K., Sanon, D., Carter, C., \& Lancellot, M. (2017). Narrative Ethnographies of Diverse Faculty in Higher Education:" Moral" Multiculturalism among Competing Worldviews. Journal of Ethnic and Cultural Studies, 4(2), 1-12.

Wooden M (1994). 'The Labour-Market Experience of Immigrants', IN: Australian Immigration: A Survey of Issues, Ed: M Wooden, R Holton, G Hugo, and J Sloan, 2nd ed. (pp. 227-292). Australia: Australian Government Publishing Service (AGPS).

Yigit, I. H., \& Tatch, A. (2017). Syrian Refugees and Americans: Perceptions, Attitudes and Insights. American Journal of Qualitative Research, 1(1), 13-31.

\section{Notes on Contributors}

Dr Yaghoob Foroutan completed $\mathrm{PhD}$ in Demography at the Australian National University's Demography \& Sociology Program, Canberra, ACT, Australia. His doctoral dissertation on Muslim/Non-Muslim women's employment differentials in Australia was awarded The W. D. Borrie Essay Prize by the Australian Population Association. He has been Post-Doctoral Fellow at the National Institute of Demographic and Economic Analysis, The University of Waikato, New Zealand (2010-2013). Dr Foroutan is Associate Professor of 
Demography at Department of Social Sciences, University of Mazandaran, Babolsar, Iran. He also holds positions as Research Associate at The University of Waikato Islamic Studies Group, Hamilton, New Zealand; and as Adjunct Fellow at School of Social Sciences and Psychology, Western Sydney University, Sydney, Australia. Dr Foroutan serves as Editorial Board Member of seven academic journals and published extensively in peer reviewed journals and edited volumes, detailed in the following links(Email Contact: y_foroutan@yahoo.com):

https://www.westernsydney.edu.au/religion_and_society/people/researchers/associate_profess or_yaghoob_foroutan

https://www.waikato.ac.nz/fass/UWISG/profile-y-foroutan.shtml

https://rms.umz.ac.ir/ foroutan/en/ 